\title{
Cholecystokinin is involved in triglyceride fatty acid uptake by rat adipose tissue
}

\author{
Adrián Plaza1,*, Beatriz Merino1,*, Victoria Cano', Gema Domínguez², Javier Pérez-Castells², \\ M Soledad Fernández-Alfonso ${ }^{3}$, Coralie Sengenès ${ }^{4}$, Julie A Chowen ${ }^{5}$ and Mariano Ruiz-Gayo' \\ 'Departamento de Ciencias Farmacéuticas y de la Salud, Facultad de Farmacia, Universidad San Pablo-CEU, Madrid, Spain \\ 2Departamento de Química y Bioquímica, Facultad de Farmacia, Universidad San Pablo-CEU, Madrid, Spain \\ 3Departamento de Farmacología, Instituto Pluridisciplinar, Universidad Complutense, Madrid, Spain \\ 4STROMALab, Université de Toulouse, CNRS ERL5311, EFS, INP-ENVT, Inserm U1031, UPS, Toulouse, France \\ ${ }^{5}$ Departamento de Endocrinología, Hospital Infantil Universitario Niño Jesús, Instituto de Investigación Sanitaria Princesa, CIBEROBN Instituto Carlos III, \\ Madrid, Spain
}

Correspondence should be addressed to M Ruiz-Gayo or J A Chowen: ruigayo@ceu.es or julieann.chowen@salud.madrid.org

*(A Plaza and B Merino contributed equally to this work)

\section{Abstract}

The incorporation of plasma triglyceride (TG) fatty acids to white adipose tissue (WAT) depends on lipoprotein lipase (LPL), which is regulated by angiopoietin-like protein-4 (ANGPTL-4), an unfolding molecular chaperone that converts active LPL dimers into inactive monomers. The production of ANGPTL-4 is promoted by fasting and repressed by feeding. We hypothesized that the postprandial hormone cholecystokinin (CCK) facilitates the storage of dietary TG fatty acids in WAT by regulating the activity of the LPL/ANGPTL-4 axis and that it does so by acting directly on CCK receptors in adipocytes. We report that administration of CCK-8 (a bioactive fragment of CCK) to rats: (i) reduces plasma ANGTPL-4 levels; (ii) represses Angptl-4 expression in WAT and (iii) simultaneously enhances LPL activity in this tissue without inducing $L p /$ expression. In vivo CCK-8 effects are specifically antagonized by the CCK-2 receptor (CCK-2R) antagonist, L-365,260. Moreover, CCK-8 downregulates Angptl-4 expression in wildtype pre-adipocytes, an effect that is not observed in engineered pre-adipocytes lacking CCK-2R. These effects have functional consequences as CCK-8 was found to promote the uptake of dietary fatty acids by WAT, as demonstrated by means of proton nuclear magnetic resonance ( $\left.{ }^{1} \mathrm{H}-\mathrm{NMR}\right)$. The efficacy of acute $\mathrm{CCK}-8$ administration was not reduced after chronic CCK-8 treatment. Moreover, the effects of CCK-8 on WAT were not associated to the increase of circulating insulin. Our results show that cholecystokinin promotes lipid storage in WAT by acting on adipocyte CCK-2R, suggesting a pivotal role for CCK in TG homeostasis.

\section{Key Words}

- adipose tissue metabolism

- angiopoietin-like protein 4

- fatty acids

- lipoprotein lipase

- nuclear magnetic resonance

\section{Introduction}

Cholecystokinin (CCK) is a postprandial hormone secreted by mucosal epithelial cells in response to fat in the lumen of the duodenum. Direct effects of CCK include satiety, inhibition of gastric emptying and stimulation of lipase release by the exocrine pancreas (Owyang \& Logsdon 2004). Moreover, CCK indirectly activates fat catabolism by cooperating both centrally and peripherally with leptin (Morton et al. 2005, Merino et al. 2008a, 
Montgomery et al. 2013, Irwin et al. 2013a) and by modulating leptin release from adipocytes (Attoub et al. 1999). CCK binds two different receptors belonging to the G protein-coupled receptor family called CCK-1 receptor (CCK-1R), located in different organs of the digestive system and in some areas of the central nervous system (CNS), such as the brainstem and the hypothalamus and CCK-2R, widely distributed throughout the CNS (Cano et al. 2003, Dufresne et al. 2006). The relevance of CCK in energy metabolism is also supported by data from OLETF rats, which lack functional CCK-1 receptors (CCK-1R) and exhibit marked obesity and type II diabetes (Moran \& Bi 2006, Schroeder et al. 2009), and CCK-knockout mice that, in contrast, are resistant to high-fat diet (HFD)-induced obesity (Lo et al. 2010). In addition, recent studies have shown that therapies based on CCK analogues alone or in combination with leptin reduce plasma triglyceride (TG) and LDL levels and also limit ectopic lipid deposition in insulin-resistant animal models (Irwin et al. $2013 a, b)$. Finally, we previously demonstrated that acute administration of the sulphated C-terminal octapeptide of CCK (CCK-8) to free-feeding rats reduces food intake and enhances enzymatic mechanisms compatible with increased catabolic activity in skeletal muscle (Merino et al. 2008a).

Together, these data support the concept that CCK is involved in regulating TG homeostasis. This regulation would be accomplished by: (i) limiting food intake; (ii) delaying gastric emptying; (iii) facilitating intestinal digestion of fat and TG absorption and (iv) enhancing fatty acid (FA) catabolism in oxidative tissues. More recently, King and coworkers demonstrated that FA uptake by adipose tissue in CCK-knockout mice is impaired (King et al. 2015, Weng et al. 2017). In a recent study, Demenis et al. (2017) reported that CCK-8 promotes CD-36-mediated FA uptake by mouse enterocytes. Based on these precedents, we hypothesized that CCK regulates TG uptake by WAT through activation of CCK receptors located in WAT. The confirmation of this hypothesis would allow one to speculate about a complementary role between CCK and insulin in regulating postprandial TG homeostasis (Czech et al. 2013). Therefore, the objective of our study was to identify the adipocyte as a target for CCK and to determine whether this is relevant in regulating TG homeostasis. As lipoprotein lipase (LPL) drives FA uptake in WAT, we wanted to further investigate the role of adipocyte CCK receptors in regulating the activity of the LPL-angipoietin-like protein 4
(ANGPTL-4) axis, which is pivotal in the uptake of plasma TG by WAT (Sukonina et al. 2006). ANGPTL-4 is a molecular chaperone that binds and inactivates LPL by promoting the dissociation of the LPL homodimer, which is the enzymatically active form of LPL. ANGPTL-4 is emerging as a new class of adipokine that appears to be regulated by nutritional status and hormones, such as insulin and glucocorticoids (Kadomatsu et al. 2011).

In this study, the effect of CCK-8, one of the most abundant circulating bioactive forms of CCK that preserves the biological activity of the native full-length hormone (Cantor \& Rehfeld 1989), was characterized both in vivo and in vitro. First, the effects of CCK-8 on ANGPTL-4 and LPL expression, LPL activity and fatty acid uptake, as determined by proton nuclearmagnetic resonance $\left({ }^{1} \mathrm{H}-\mathrm{NMR}\right)$, were characterized in rat WAT. Second, CCK-8's effects were corroborated in pre-adipocytes obtained from rat visceral and subcutaneous WAT. The specificity of effects of CCK was assessed by means of (i) in vivo-administered CCK receptor antagonists and (ii) pre-adipocytes in which CCK receptors were silenced.

\section{Material and methods}

\section{Chemicals}

The CCK-1R antagonist, SR-27,897 (1-[2-4-(2-chlorophenyl) thiazol-2-yl-aminocarbonyl]-indolylacetic acid), was kindly provided by Sanofi-Synthelabo, France (Poncelet et al. 1993). The CCK-2R antagonist, L-365,260 [(3R-(+)2,3-dihydro-1-methyl-2-oxo-5-phenyl-1H-1,4-benzo diazepin-3-yl)-N'-(3-methylphenyl)urea], was a gift of Merck Sharp and Dohme Research Laboratories, USA (Chang et al. 1989). Other chemicals were from Sigma.

\section{Experimental design}

The studies presented here conform to the Guide for the Care and Use of Laboratory Animals (European Communities Council Directive 86/609/EEC) and were approved by the Ethics Committee of the Universidad San Pablo-CEU. The in vivo studies were carried out in adult male Sprague-Dawley rats during the nocturnal period of the circadian cycle and under similar experimental conditions to those used in our laboratory to investigate the physiological role of CCK on other aspects of energy metabolism (Merino et al. 2008a,b). 


\section{Experiment 1: Acute treatment with CCK-8}

Thirty-six 14-week-old male Sprague-Dawley rats (Harlan, Barcelona, Spain) were housed individually under standard conditions $\left(12 \mathrm{~h}\right.$ light $/ 12 \mathrm{~h}$ dark, $22^{\circ} \mathrm{C}$; lights on at 08:00) on corncob bedding with standard rodent chow (Teklad; Harlan) and water ad libitum (day 14). In order to minimize the number of rats, the experiment was organized in three sequential assays that were carried out at 1-week intervals in the same animals, which were randomly assigned in each assay to either intervention or control groups. As schematized in Fig. 1, the assays performed were: (1) a dose-response effect of CCK-8, in order to identify the dose of CCK-8 able to modulate plasma ANGPTL-4 levels (day $0)$; (2) an antagonism experiment, aimed at identifying the CCK receptor subtype involved in the effect of CCK-8 (day 7) and (3) an antagonism experiment carried out in rats that acutely consumed a diet containing elevated amounts of linolenic and linoleic acids (LIN), which were used as a probe to trace dietary TGs.

In assay 1 , rats were randomly assigned to groups receiving treatment with either saline or CCK-8 (saline, $0.025,0.5$ and $10 \mu \mathrm{g} / \mathrm{kg} ; n=6 /$ group). The day of the experiment, rats were fasted from 09:00 until 18:00 and then fed ad libitum with standard chow. At 22:00, rats were weighed and administered (i.p.) either saline or CCK-8. After $2 \mathrm{~h}$, food intake and BW were determined and blood samples were obtained by incision of the tail vein. The wound was then washed with antimicrobial solution of povidone-iodide. A pair-feeding assay, where rats were restricted to the amount of food consumed by rats receiving $10 \mu \mathrm{g} / \mathrm{kg}$ CCK-8, was carried out to explore the eventual contribution of reduced food intake

\section{Acute treatment}

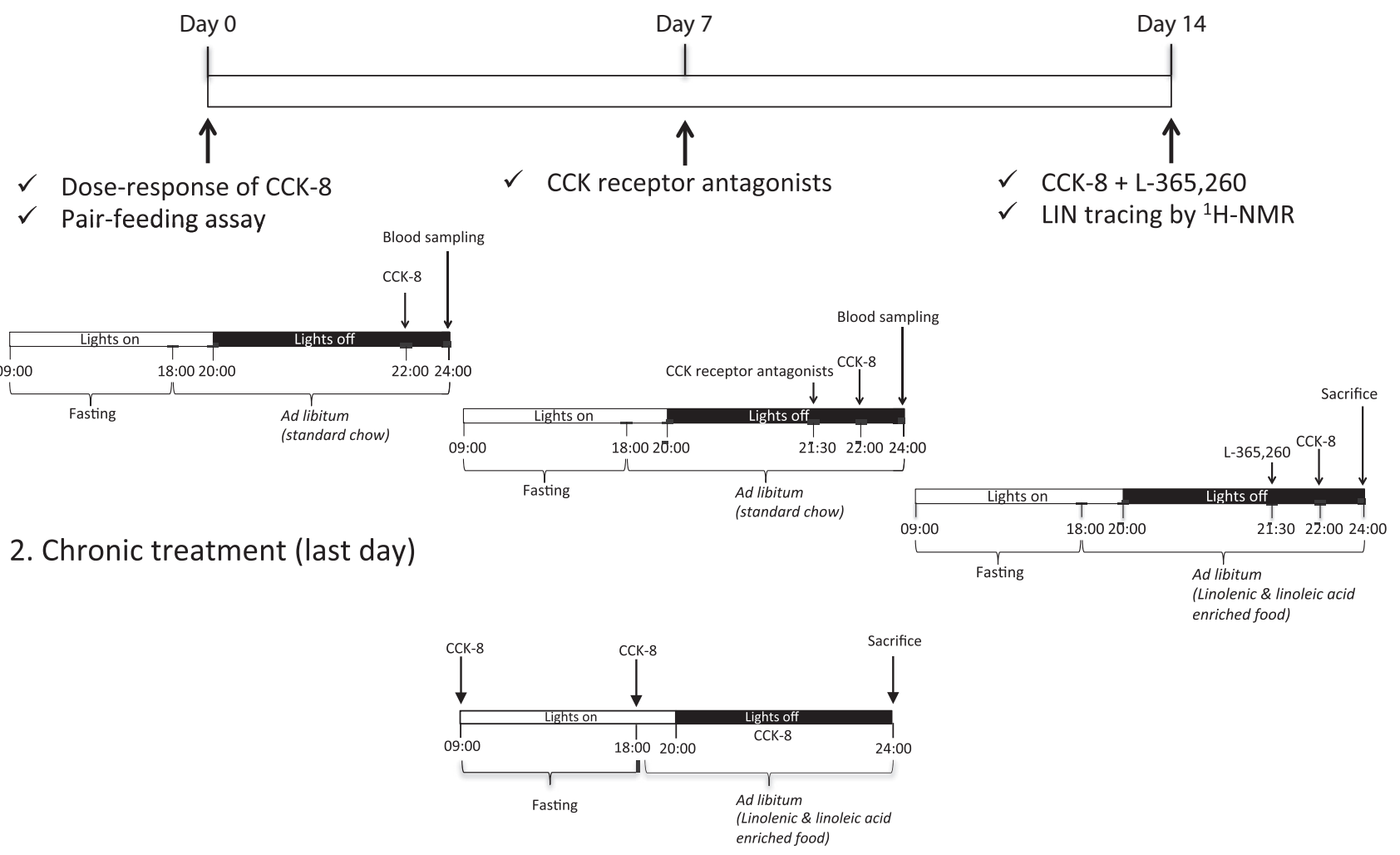

Figure 1

Schematic illustration of acute and chronic treatment with CCK-8. (1) Acute treatment with CCK-8: The experiment was organized in three sequential assays: day 0) dose-response effect of CCK-8; day 7) antagonism of the effect of CCK-8 by selective CCK-1 (SR-27,897) and CCK-2 receptor antagonists $(L-365,260)$ and day 14) antagonism of the effect of CCK-8 by L-365,260 in rats that consumed a diet containing elevated amounts of LIN. On days 0,7 and 14, rats were fasted from 09:00 until 18:00 and then fed ad libitum either with standard chow (days 0 and 7) or with LIN-enriched food (day 14). On day 0 , rats received CCK-8 at 22:00 and a sample of blood was collected at 24:00. Both food intake and BW variation between 22:00 and 24:00 were monitored. On day 7, animals received either L-365,260 or SR-27,897 at 21:30 and a dose of CCK-8 at 22:00. Similarly, on day 14, rats received L-365,260 and CCK-8 and were killed at 24:00. White adipose tissues were collected to quantify LIN by ${ }^{1} \mathrm{H}-\mathrm{NMR}$. (2) Chronic treatment with CCK-8: CCK-8 was administered twice a day (09:00 and 18:00) during 11 days to free feeding rats. On day 12, rats received the same pharmacological treatment but were fasted from 09:00 until 18:00, then fed ad libitum either with standard chow or with LIN-enriched food, and killed at 24:00. 
to the effect of CCK-8 (control and pair-fed groups, $n=6 /$ group).

In assay 2 , animals were randomly re-assigned to a similar feeding protocol. In this case, at 21:30, animals received saline $(n=12), \mathrm{L}-365,260$ (a CCK-2R antagonist; $1 \mathrm{mg} / \mathrm{kg} ; n=12$ ) or SR-27,897 (a CCK-1R antagonist; $0.3 \mathrm{mg} / \mathrm{kg} ; n=12)$ s.c. Thirty minutes later, rats were treated i.p. with either saline (saline +saline, $n=6$; L-365,260 + saline, $n=6 ;$ SR-27, $897+$ saline, $n=6$ ) or $10 \mu \mathrm{g} / \mathrm{kg}$ CCK-8 (saline+CCK-8， $n=6$; L-365,260+CCK-8, $n=6$; SR-27,897+CCK-8, $n=6$ ). At 24:00, animals and food were weighed and a sample of blood was obtained from the caudal vein.

In assay 3, twenty rats were fasted from 09:00 until 18:00 and then fed ad libitum with pellets (cookies) prepared from ground standard chow, flaxseed oil and egg white $(6 / 4 / 2)$. Rats were randomly assigned to receive either saline $(n=10)$ or L-365,260 $(1 \mathrm{mg} / \mathrm{kg} ; n=10)$ at 21.30 . Five animals of each group received either saline or CCK-8 $(10 \mu \mathrm{g} / \mathrm{kg})$ at $22: 00$. Animals were killed by decapitation, under inhalational anesthesia with isoflurane, at 24:00 and perirenal (Per-WAT), mesenteric (Mes-WAT) and subcutaneous (Sc-WAT) WAT were dissected and frozen in liquid nitrogen. Flaxseed oil was used because of its elevated content in linolenic $(>50 \%)$ and linoleic acids $(>15 \%)$, which are absent in the standard rodent chow, and therefore, useful as a probe to trace dietary TGs by ${ }^{1} \mathrm{H}-\mathrm{NMR}$. Blood was collected for plasma biochemistry analysis. Per-WAT, Mes-WAT and Sc-WAT were collected for LIN quantification, gene expression analysis and LPL activity measurement. Both doses and timing for drug administration, as well as sampling and the sacrifice of animals were scheduled on the basis of previous studies by our group (Ruiz-Gayo et al. 2000, Cano et al. 2008, Merino et al. 2008a) showing that the efficacy of effects of CCK-8 on energy metabolism was optimal when administered during the initial phase of the dark period of the circadian cycle.

\section{Experiment 2: Chronic treatment with CCK-8}

Chronic treatment with CCK-8 was carried out in order to explore an eventual loss of efficacy of CCK-8. Another group of 14-week-old male Sprague-Dawley rats was submitted to chronic treatment (i.p., twice daily, at 09:00 and 18:00) with either saline $(n=6)$ or CCK-8 $(n=6$, $10 \mu \mathrm{g} / \mathrm{kg}$ ) and maintained on standard rodent chow. On day 12 of treatment, animals were administered their corresponding treatment at 09:00 and fasted until 18:00. They were then given free access to the flaxseed oil pellets described earlier. Rats received saline or CCK-8 at 18:00 and were decapitated at 24:00.

\section{Plasma biochemistry and tissue lipid quantification}

Glucose (GTM, Roche), triglycerides (Biolabo, Maizy, France) and non-esterified free fatty acids (NEFA; Wako Bioproducts) were measured by colorimetric methods. Plasma leptin, insulin and CCK levels were analyzed by EIA (Phoenix Pharmaceuticals, Karlsruhe, Germany, for leptin and CCK, and Mercodia, Uppsala, Sweden, for insulin). Lipids were extracted from WAT and liver in chloroform/methanol (2/1) following the method of Folch with modifications (Herrera \& Ayanz 1972).

\section{Western blotting of ANGPTL-4}

Plasma samples (7-10 $\mu$ g proteins) were loaded in Laemmli buffer and size separated by SDS-PAGE. After protein transfer to PVDF membranes (GE Healthcare) and blocking with 5\% nonfat dried milk/Tween-PBS $(1 \mathrm{~h})$, a commercially available rabbit polyclonal antibody validated for Western blotting and directed against the N-terminal domain of ANGPTL-4 (1:1000; Abcam ab2920), which is the domain interacting with LPL (Sukonina et al. 2006), was applied overnight at $4^{\circ} \mathrm{C}$. After washing, an IgG-peroxidase-conjugated secondary antibody was applied for $1 \mathrm{~h}$ (1:5000). Blots were incubated in chemiluminescence reagents (ECL Prime, GE Healthcare) and bands were detected using the ChemiDoc XRS+ Imaging System (BioRad). ANGPTL-4 values were normalized to serum albumin levels (Ponceau S Red; Sigma). Values are expressed as percent of the saline group.

\section{Lipoprotein lipase activity assay}

Fifty milligrams of WAT were homogenized in $0.8 \mathrm{~mL}$ Tris- $\mathrm{HCl} \quad(0.2 \mathrm{~mol} / \mathrm{L}, \quad \mathrm{pH}=8.2)$. After centrifugation $(10 \mathrm{~min}, 1250 \boldsymbol{g})$, the aqueous phase was transferred to Eppendorf tubes containing $50 \mu \mathrm{L}$ preheated fetal calf serum $\left(60^{\circ} \mathrm{C} ; 10 \mathrm{~min}\right)$. Proteins were precipitated with cold acetone $\left(-20^{\circ} \mathrm{C}\right)$, and then washed with ether and dried. The resulting powder was re-suspended in $1 \mathrm{~mL} 0.05 \mathrm{~mol} / \mathrm{L}$ $\mathrm{NH}_{4} \mathrm{OH} / \mathrm{NH}_{4} \mathrm{Cl}$ buffer $(\mathrm{pH}=8.1)$. Samples were assayed for LPL activity as previously described (Sugden et al. 1993). Briefly, $0.2 \mathrm{~mL}$ samples were incubated $\left(30 \mathrm{~min}, 37^{\circ} \mathrm{C}\right)$ in a buffer prepared from $0.05 \mathrm{~mL}$ water, $0.04 \mathrm{~mL} 0.2 \mathrm{~mol} / \mathrm{L}$ Tris-HCl buffer $(\mathrm{pH}=8.2 ; 0.15 \mathrm{~mol} / \mathrm{L} \mathrm{NaCl}, 6 \% \mathrm{BSA})$, $0.02 \mathrm{~mL}$ preheated fetal calf serum and $0.04 \mathrm{~mL}$ $\mathrm{C}^{14}$-labeled triolein (Perkin-Elmer) solution $(69 \mathrm{mg}$ cold 
triolein, $3.3 \mathrm{mg}$ lecithin and $462 \mathrm{kBq}{ }^{14} \mathrm{C}$-triolein, and $5 \mathrm{~mL}$ glycerol). The enzymatic reaction was stopped by the addition of $3 \mathrm{~mL}$ chloroform/heptane/methanol $(1 / 1 / 1)$, and free ${ }^{14} \mathrm{C}$-oleic acid extracted with $1 \mathrm{~mL} 0.1 \mathrm{M}$ $\mathrm{KBO}_{3} / \mathrm{K}_{2} \mathrm{CO}_{3}(\mathrm{pH}=8.5)$ and quantified. All samples were run in triplicate. Values are expressed in fkat/mg prot.

\section{Evaluation of dietary triglyceride uptake by ${ }^{1} \mathrm{H}$-nuclear magnetic resonance}

WAT samples were processed for total lipid extraction with chloroform/methanol. Ten milligrams of the extract were dissolved in deuterated chloroform and ${ }^{1} \mathrm{H}-\mathrm{NMR}$ spectra recorded at $400 \mathrm{MHz}$ in a Bruker AdvanceIII apparatus (Bruker, Ettlingen, Germany), at room temperature. Total LIN content was estimated by integrating signals corresponding to methylenic protons located in positions 11 and 14 (2.77 ppm; $\operatorname{LIN}_{11,14}$ ), which are unique in LIN as they have two neighboring double bonds. Integration values were referred to signal intensities of the $\alpha$-protons (2.31 ppm), which are common to all fatty acids (Knothe \& Kenar 2004). This ratio $\left(\operatorname{LIN}_{11,14} / \alpha\right)$ allows the comparison of the amount of LIN between controls and CCK-8-treated animals. Although ${ }^{1} \mathrm{H}-\mathrm{RMN}$ has not been generally used for quantification of complex mixtures due to signal overlapping, it allows the simultaneous determination and quantification of multiple analytes in biological samples (Pauli et al. 2012) and has been validated for TG quantification in rat adipose tissue (Mosconi et al. 2011).

\section{Cholecystokinin receptor gene silencing}

Differentiated pre-adipocytes (Supplementary Data 1 and Supplementary Fig. 2, see section on supplementary data given at the end of this article) were transfected with siRNAs for Cckar and Cckbr (s234619 and s218025, respectively; Life Technologies) in 24-well plates. Cckar and $C c k b r$ are the genes encoding for CCK-1R and CCK-2R proteins, respectively. Briefly, for each well, siRNAs $(40 \mathrm{nmol} / \mathrm{L})$ were diluted in $50 \mu \mathrm{L}$ Opti-MEM (Life Technologies), incubated $15 \mathrm{~min}\left(25^{\circ} \mathrm{C}\right)$ and then added to a solution containing $3 \mu \mathrm{L}$ lipofectamine RNAiMAX (Life Technologies) diluted in $50 \mu \mathrm{L}$ Opti-MEM. After 15 additional $\min \left(25^{\circ} \mathrm{C}\right), 100 \mu \mathrm{L}$ of the mixture were added dropwise to wells containing $400 \mu \mathrm{L}$ Opti-MEM. The medium was replaced by differentiation media after overnight incubation. Two days after transfection, the medium was changed to $\alpha$-MEM containing $0.1 \%$ BSA (Lee et al. 2014), then CCK-8 $\left(10^{-6} \mathrm{~mol} / \mathrm{L}\right)$ was added and incubated for $2 \mathrm{~h}\left(37^{\circ} \mathrm{C}, 5 \% \mathrm{CO}_{2}\right)$. Media was removed and mRNA ( 2 wells) was extracted as detailed below. Assays were replicated three times. Positive controls for transfection were performed by using Block-iT Alexa Fluor Red (Life Technologies). A Silencer Select Negative Control (4390843, Thermo Fisher Scientific) was used. All samples were run in pentaplicate.

\section{Quantitative real-time PCR}

Total RNA was extracted by using the Tri-Reagent protocol (Sigma). cDNA was then synthesized from $1 \mu \mathrm{g}$ total RNA by using a high-capacity cDNA RT kit (Applied Biosystems). Quantitative RT-PCR was performed by using designed primer pairs (Integrated DNA Technologies, USA) for Angptl-4 (forward 5'-TCCGAGGGGACCTTAACTGT-3'; reverse 3'-CCGTTGCCGTGG AATAGAGT-5'), Cckar (forward 3'-GTTGCCAAGTGACGCTATGC-3', reverse 5'-CCACCACCATCACAATCCCA-3'), $\quad c c k b r$ (forward 3'-CGGGTGTCTCCCTTCTCAAC-5', reverse 5'-CGTTTCCGCCAACACTCATC-3') and Lpl (forward 5'-TCTAACTGCCACTTCAACCACAGCAG-3', reverse 5'-CAAGACTGTACCCTAAGAGGTGGAC-3'). SsoAdvanced Universal SYBR Green Supermix (Bio-Rad) was used for amplification according to the manufacturer's protocols in an ABI PRISM 7000 Sequence Detection System (Applied Biosystems). Values were normalized to the housekeeping gene actin (Rn00667869_m1) and $18 \mathrm{~S}$ ribosomal RNA (Rn03928990_g1). The $\Delta \Delta \mathrm{C}(\mathrm{T})$ method was used to determine relative expression levels. Statistics were performed using $\Delta \Delta \mathrm{C}(\mathrm{T})$ values (Livak \& Schmittgen 2001). All samples were run in duplicate.

\section{Statistics}

Individual effects within a given group were analyzed by using a one-way ANOVA, followed by Newman-Keuls' post hoc test. Correlations were analyzed by calculating Pearson correlation coefficients. Statistical significance was set at $P<0.05$. All statistics were performed using Graph Pad Prism 7 (GraphPad Software).

\section{Results}

Acute treatment with CCK-8 reduced plasma ANGPTL-4 levels

As illustrated in Fig. 2A and B, CCK-8 $(10 \mu \mathrm{g} / \mathrm{kg})$ inhibited food intake $(P<0.05)$ and reduced BW $(P<0.05)$. Moreover, CCK-8 reduced circulating ANGPTL-4 levels (Fig. 2C; $P<0.05$ ), an effect that cannot be attributed to 


\begin{tabular}{l|l|l|c|c|}
$\begin{array}{l}\text { Journal of } \\
\text { Endocrinology }\end{array}$ & A Plaza, B Merino et al. & $\begin{array}{l}\text { Cholecystokinin and adipose } \\
\text { tissue metabolism }\end{array}$ & $\mathbf{2 3 6 : 3}$ & $\mathbf{1 4 2}$ \\
\hline
\end{tabular}

A

B
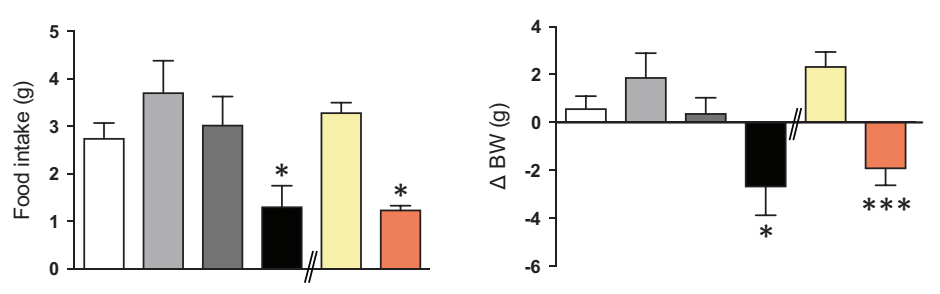


$\square$ Saline $\square$ CCK-8 (0.025 $\mu \mathrm{g} / \mathrm{kg}) \quad \square$ CCK-8 $(0.5 \mu \mathrm{g} / \mathrm{kg}) \quad \square$ CCK-8 $(10 \mu \mathrm{g} / \mathrm{kg}) \quad \square$ Ad libitum $\square$ Pair-Fed

D

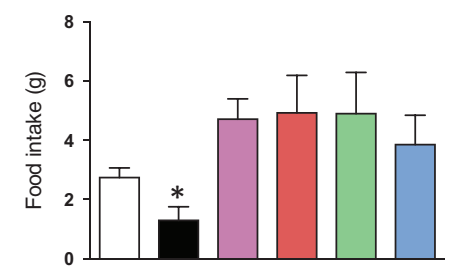

E

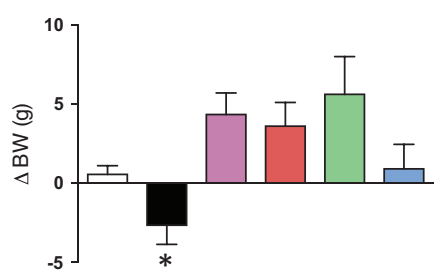

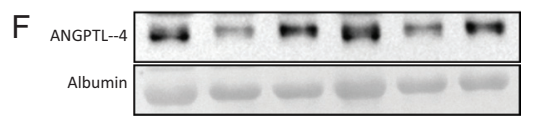

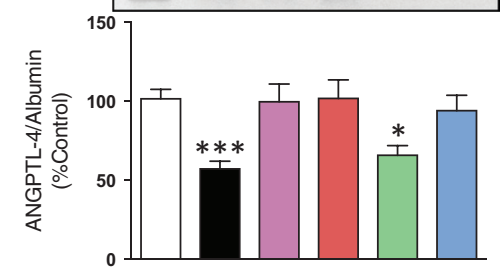

\begin{tabular}{|c|c|c|}
\hline$\square$ Saline & CCK-8 $(10 \mu \mathrm{g} / \mathrm{kg})$ & $\square$ SR-27,897 (0.3 mg/kg) \\
\hline$\square$ L-365,260 (1 mg/kg) & $\square$ SR-27,897 + CCK-8 & $\square$ L-365,260 + CCK-8 \\
\hline
\end{tabular}

\section{Figure 2}

Effect of acute treatment with CCK-8 and CCK receptor antagonists on food intake, body weight and plasma ANGPTL-4. Effect of CCK-8 on food intake (A), body weight (B) and ANGPTL-4 plasma levels (C). Pair fed rats received pre-weighed food equivalent to food-intake observed in rats receiving $10 \mu \mathrm{g} / \mathrm{kg}$ CCK-8. Panels (D), (E) and (F) illustrate the effect of SR-27,897 (CCK-1 receptor antagonist) and L-365,260 (CCK-2 receptor antagonist) on the decrease in food intake, body weight and plasma ANGPTL-4 triggered by $10 \mu \mathrm{g} / \mathrm{kg}$ CCK-8, respectively. Values are means \pm S.E.M. $(n=6)$. $P<0.05$; $* * * P<0.001$, compared to the control saline group (Newman-Keuls' test).

the inhibition of food intake triggered by CCK-8 as pairfeeding to $10 \mu \mathrm{g} / \mathrm{kg}$ CCK-8-treated rats (Fig. 2A and B) did not modify plasma ANGPTL-4 (Fig. 2C). The CCK-1R antagonist SR-27,897 blocked the effect of CCK-8 on food intake (Fig. 2D; $P<0.05$ ) and BW (Fig. 2E; $P<0.05$ ). These effects were also antagonized by the CCK-2R antagonist, L-365,260. In contrast, the effect of CCK-8 on ANGPTL-4 levels was selectively blocked by L-365,260 (Fig. 2F; $P<0.01)$. Circulating levels of glucose, TG, NEFA, leptin, insulin and CCK were unaffected by CCK-8 (Table 1).
Acute treatment with CCK-8 repressed Angpt/-4 expression and simultaneously enhanced

LPL activity and TG content in subcutaneous and visceral WAT

WAT deposits were weighed and compared between the different groups of animals. CCK-8 did not significantly modify the amount of WAT deposits (Fig. 3A). However, LPL activity (Fig. 3B), but not Lpl gene expression (Fig. 3C), was significantly enhanced by CCK-8 in both Sc-WAT

Table 1 Effect of acute and chronic treatment with CCK-8 on plasma parameters.

\begin{tabular}{lcc}
\hline & \multicolumn{2}{c}{ Acute treatment } \\
\cline { 3 - 4 } \cline { 3 - 4 } Glucose $(\mathrm{mg} / \mathrm{dL})$ & Saline & CCK-8 $(10 \mu \mathrm{g} / \mathrm{kg})$ \\
TG $(\mathrm{mg} / \mathrm{dL})$ & $110.5 \pm 3.4$ & $110.8 \pm 2.3$ \\
NEFA $(\mathrm{mg} / \mathrm{dL})$ & $159.6 \pm 25.7$ & $116.6 \pm 20.8$ \\
Insulin $(\mathrm{ng} / \mathrm{mL})$ & $43.4 \pm 5.1$ & $35.3 \pm 3.4$ \\
Leptin $(\mathrm{ng} / \mathrm{mL})$ & $0.77 \pm 0.13$ & $0.83 \pm 0.18$ \\
CCK $(\mathrm{ng} / \mathrm{mL})$ & $2.3 \pm 0.5$ & $4.1 \pm 1.2$ \\
\hline
\end{tabular}

\begin{tabular}{cc}
\hline \multicolumn{2}{c}{ Chronic treatment } \\
\hline Saline & CCK-8 $(10 \mu \mathrm{g} / \mathrm{kg})$ \\
\hline $101.9 \pm 4.0$ & $90.9 \pm 2.6$ \\
$152.6 \pm 12.7$ & $114.4 \pm 10.3$ \\
$37.8 \pm 2.4$ & $31.9 \pm 1.2^{*}$ \\
$1.85 \pm 0.24$ & $0.92 \pm 0.14^{*}$ \\
$0.87 \pm 0.1$ & $0.26 \pm 0.1^{*}$ \\
$0.47 \pm 0.01$ & $0.53 \pm 0.06$
\end{tabular}

Acute treatment with a single dose of CCK-8 $(10 \mu \mathrm{g} / \mathrm{kg})$ had no effect on plasma levels of glucose, triglycerides (TG), non-esterified fatty acids (NEFA), insulin, leptin and total cholecystokinin immunoreactivity (CCK). Chronic CCK-8 treatment had no effect on plasma glucose, NEFA or CCK, but reduced TG, insulin and leptin levels. Values are means \pm s.E.M. $(n=6)$.

$* P<0.05$ compared to the control group (Newman-Keuls' test). 


\begin{tabular}{l|l|l|l|l|}
$\begin{array}{l}\text { Journal of } \\
\text { Endocrinology }\end{array}$ & A Plaza, B Merino et al. & $\begin{array}{l}\text { Cholecystokinin and adipose } \\
\text { tissue metabolism }\end{array}$ & $\mathbf{2 3 6 : 3}$ & $\mathbf{1 4 3}$ \\
\hline
\end{tabular}
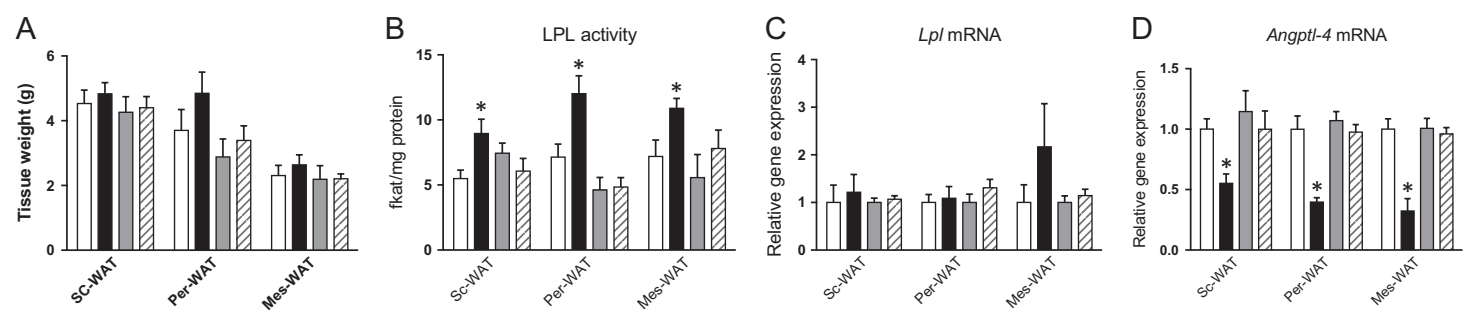

$\mathrm{E}_{\mathrm{CH}_{3}-\left(\mathrm{CH}_{2}\right)_{12}-\mathrm{CH}_{2}-\mathrm{CH}_{2}-\mathrm{COOH} \text { Palmitic acid }}^{\alpha}$

$\mathrm{CH}_{3}-\left(\mathrm{CH}_{2}\right)_{6}-\mathrm{CH}_{2}-\mathrm{CH}=\mathrm{CH}-\mathrm{CH}_{2}-\left(\mathrm{CH}_{2}\right)_{4}-\mathrm{CH}_{2}-\mathrm{CH}_{2}-\mathrm{COOH}$ Oleic acid

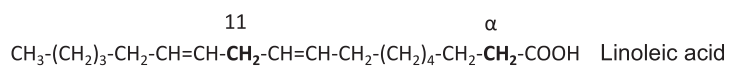

$14 \quad 11 \quad \alpha$

$\mathrm{CH}_{3}-\mathrm{CH}_{2}-\mathrm{CH}=\mathrm{CH}-\mathrm{CH}_{2}-\mathrm{CH}=\mathrm{CH}-\mathrm{CH}_{2}-\mathrm{CH}=\mathrm{CH}-\mathrm{CH}_{2}-\left(\mathrm{CH}_{2}\right)_{4}-\mathrm{CH}_{2}-\mathrm{CH}_{2}-\mathrm{COOH}$ Linolenic acid
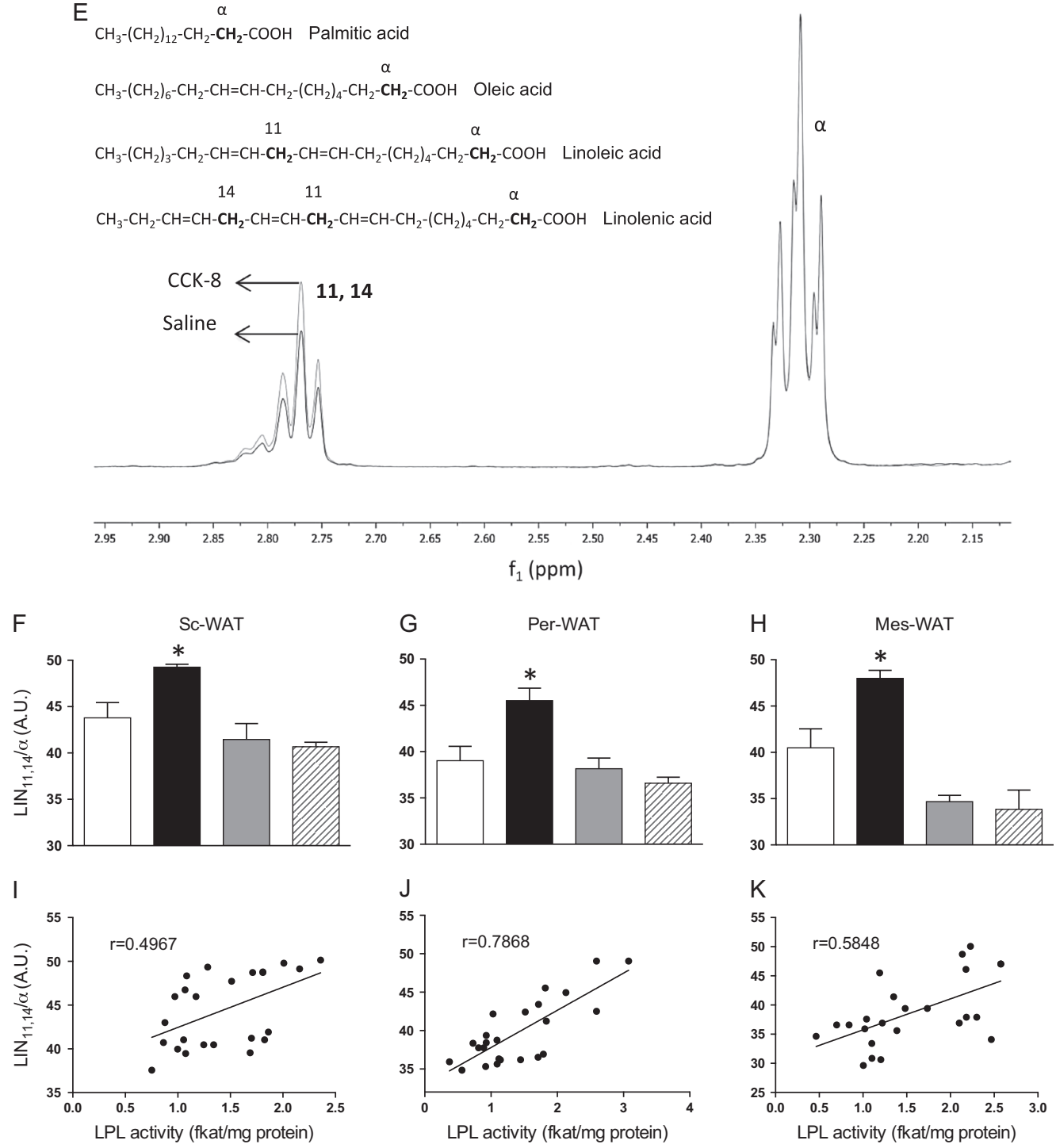

Saline

CCK-8 $(10 \mu \mathrm{g} / \mathrm{kg})$

$\mathrm{L}-365,260(1 \mathrm{mg} / \mathrm{kg})$

W $\mathrm{L}-365,260+\mathrm{CCK}-8$

Figure 3

Effect of acute treatment with CCK-8 and the CCK-2R antagonist, L-365,260, on adiposity, LPL activity, Angptl-4 expression and TAG uptake in subcutaneous and visceral adipose WAT. (A) Effect of $10 \mu \mathrm{g} / \mathrm{kg}$ CCK-8 and L-365,260 on the amount of subcutaneous, perirenal and mesenteric WAT. (B) LPL activity, but not Lp/ expression (C), was increased by CCK-8 in all WAT deposits analyzed and its effect was antagonized by L-365,260. (D) Angpt/-4 expression was repressed by CCK-8 in all WAT deposits. L-365,260 prevented the effect of CCK-8. Angptl-4 values were normalized to the housekeeping gene $\beta$-actin and $18 \mathrm{~S}$ ribosomal RNA. (E) Typical ${ }^{1} \mathrm{H}-\mathrm{NMR}$ records corresponding to a total lipid extract of WAT from control (black line) and CCK-8-treated rats (grey line) that consumed a linolenic/linoleic-enriched diet previously to treatment with $10 \mu \mathrm{g} / \mathrm{kg}$ CCK-8. CCK-8 enhanced the amount of linolenic/linoleic acid in the subcutaneous (F), perirenal (G), and mesenteric WAT (H) and its effect was prevented by L-365,260. Correlations between $\mathrm{LIN}_{11,14} / \alpha$ and LPL activity (I, J and K). Values are means \pm S.E.M. $(n=5)$. ${ }^{*} P<0.05 ; * * P<0.01$ and $* * * P<0.001$, compared to the control group (Newman Keuls' test). 
and Vis-WAT ( $P<0.05$ in all tissues). In addition, CCK-8 reduced Angptl-4 mRNA levels in these WAT deposits (Fig. 3D; $P<0.05$ ).

Figure $3 \mathrm{E}$ shows a typical ${ }^{1} \mathrm{H}-\mathrm{NMR}$ spectrum of total lipids obtained from Per-WAT samples of rats that ate a linolenic/linoleic-rich (LIN) diet and that were treated with either saline (black line) or CCK-8 (grey line). Signals corresponding to methylene protons 11 and 14 from LIN, which appear as a triplet at $2.77 \mathrm{ppm}$, were integrated and normalized to the integral of the multiplet corresponding to the $\alpha$-protons at $2.31 \mathrm{ppm}$, which is common to all fatty acids. This was used to estimate the relative proportion of LIN in each sample and evaluate the influence of CCK-8 on total LIN uptake. As illustrated in Fig. 3F, G and H, CCK-8 enhanced the ratio $\operatorname{LIN}_{11,14} / \alpha$ in all Sc-, Per- and Mes-WAT deposits $(P<0.05)$, and this effect was abolished by L-365,260. Positive correlations between $\operatorname{LIN}_{11,14} / \alpha$ and LPL activity were identified in Sc-WAT (Fig. 3I; $P<0.05$ ), Per-WAT (Fig. 3J; $P<0.001$ ) and Mes-WAT (Fig. 3K; $P<0.01$ ).

\section{The effect of CCK-8 on Angptl-4 expression was abolished by silencing Cckbr expression in adipocyte precursor cells}

Because in vivo assays strongly suggested that CCK-2R is involved in regulating Angptl-4 expression in adipose tissue, an in vitro experiment carried out in pre-adipocytes was designed to confirm this hypothesis. Pre-adipocytes were differentiated from the subcutaneous and visceral WAT-derived stromal vascular fractions (Supplementary Data 1 and Supplementary Fig. 2) and transfected with siRNAs for Cckar (corresponding to CCK-1R protein) or $C c k b r$ (corresponding to CCK-2R protein). The effectiveness of gene knockdown on Cckar and $C c k b r$ mRNA levels is illustrated in panels $4 \mathrm{~A}$ and $4 \mathrm{~B}$ (Cckar) and $4 \mathrm{C}$ and $4 \mathrm{D}(C c k b r)$, respectively.

Figure 4E and F show the effect of CCK-8 on Angptl-4 expression in visceral and subcutaneous pre-adipocytes after Cckar and Cckbr mRNA silencing. CCK-8 repressed Angptl-4 expression, and this effect was specifically abolished in cells carrying the silenced $C c k b r$ gene $(P<0.05)$. CCK-8 had no effect on $\mathrm{LPl}$ gene expression (Fig. $4 \mathrm{G}$ and $\mathrm{H}$ ).

\section{Chronic treatment with CCK-8 also reduced Angptl-4 expression and LPL activity in adipose tissue}

Figure 5 illustrates the effect of chronic CCK- 8 treatment on the same parameters analyzed in the previous study.
Under these conditions, chronic CCK-8 limited BW gain $(5.20 \pm 2.04 \mathrm{~g}$ in the CCK-treated group vs $11.00 \pm 2.45 \mathrm{~g}$ in the saline group). The last injection of CCK- 8 caused a decrease in BW $(-1.40 \pm 0.30 \mathrm{~g}$ in CCK-8-treated vs $0.70 \pm 0.20 \mathrm{~g}$ in saline-treated rats; $P<0.05$ ), measured $6 \mathrm{~h}$ after the last CCK-8 administration. Circulating levels of ANGPTL-4 were reduced by chronic CCK-8 (Fig. 5A; $P<0.01)$. In addition, a robust decrease of Angptl-4 mRNA expression (Fig. $5 \mathrm{~B} ;{ }^{* *} P<0.01,{ }^{* *} P<0.001$ ), together with an enhancement of LPL activity (Fig. $5 \mathrm{C}$; ${ }^{*} P<0.05$, $\left.{ }^{* *} P<0.01\right)$, was detected in both visceral and subcutaneous adipose tissues of rats chronically treated with CCK-8. Chronic CCK-8 had no effect on $\mathrm{Lpl}$ expression (Fig. 5D).

Although the weights of the adipose depots were not modified by chronic CCK-8 (Fig. 5E), LIN uptake was significantly increased by CCK-8 in Sc-WAT and Vis-WAT (Fig. 5F, $\mathrm{G}$ and $\mathrm{H} ; \mathrm{P}<0.05$ ). As observed in the case of acute CCK-8 treatment, a positive linear correlation between $\operatorname{LIN}_{11,14} / \alpha$ and LPL activity was detected in Sc-WAT (Fig. 5I; $P<0.001$ ), Per-WAT (Fig. 5J; $P<0.01$ ) and Mes-WAT (Fig. 5K; $P<0.05$ ). Chronic CCK-8 treatment had no effect on plasma glucose, NEFA or CCK, but reduced TG, leptin and insulin levels (Table 1).

Chronic CCK-8 treatment had no effect on food intake during the treatment (Fig. 4 and supplementary data).

\section{Discussion}

This study reports the first evidence of CCK-8-regulated hydrolysis of TG and increased uptake of FAs by WAT and supports a new role for CCK in connecting the gut and WAT to drive TG homeostasis. We demonstrate that CCK-8, by acting on adipocyte CCK-2R, reduces WAT Angptl-4 gene expression as well as circulating ANGPTL-4 levels, leading to the activation of WAT LPL (Sukonina et al. 2006). This mechanism suggests the existence of an axis connecting CCK-2R, ANGPTL-4 and LPL (Fig. 6) that would drive the incorporation of dietary fat into WAT and would be involved in the expandability of WAT deposits during postprandial periods.

The most important finding of our study is the downregulation of Angptl-4 mRNA levels together with the increase in LPL activity in Sc and visceral WAT evoked by CCK-8, which occurs concomitantly with the reduction of circulating ANGPTL-4. The activation of LPL by CCK-8 is not linked to the increase of adipose Lpl gene expression, since mRNA $L p l$ mRNA levels were not modified by CCK-8. Likewise, the lack of effect on plasma ANGPTL-4 levels observed in pair-fed rats allows 


\begin{tabular}{l|l|l|l|l|}
$\begin{array}{l}\text { Journal of } \\
\text { Endocrinology }\end{array}$ & A Plaza, B Merino et al. & $\begin{array}{l}\text { Cholecystokinin and adipose } \\
\text { tissue metabolism }\end{array}$ & $\mathbf{2 3 6 : 3}$ & $\mathbf{1 4 5}$ \\
\hline
\end{tabular}

A Visceral pre-adipocytes

Cckar mRNA
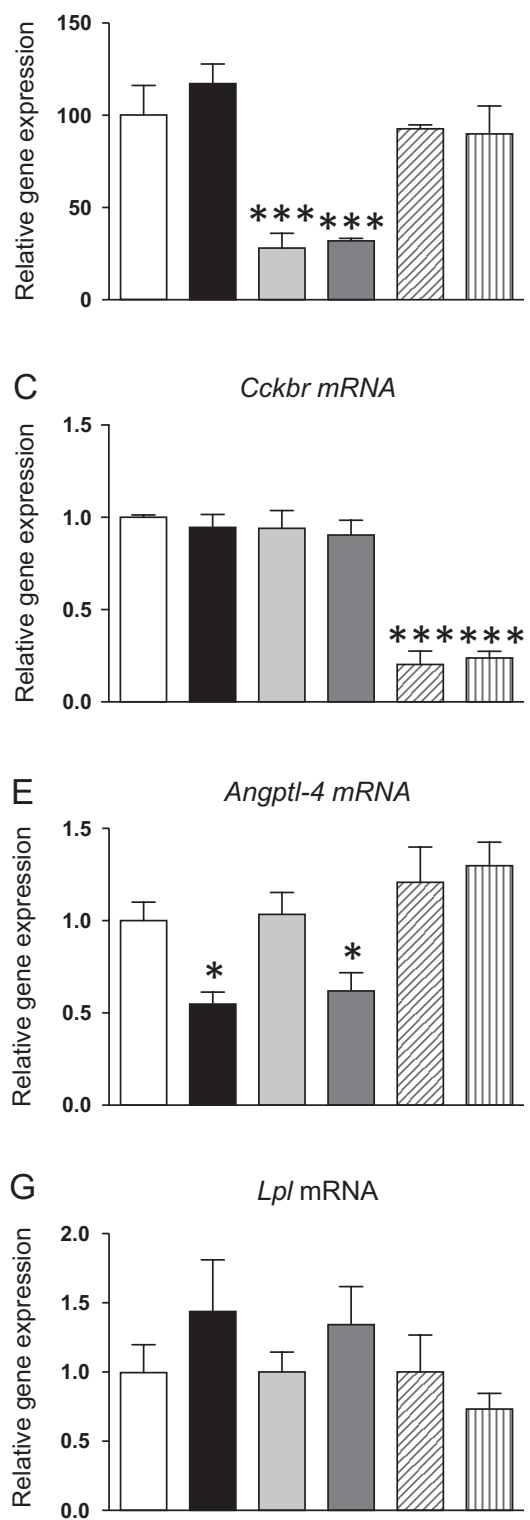

\section{B Subcutaneous pre-adipocytes}

Cckar mRNA
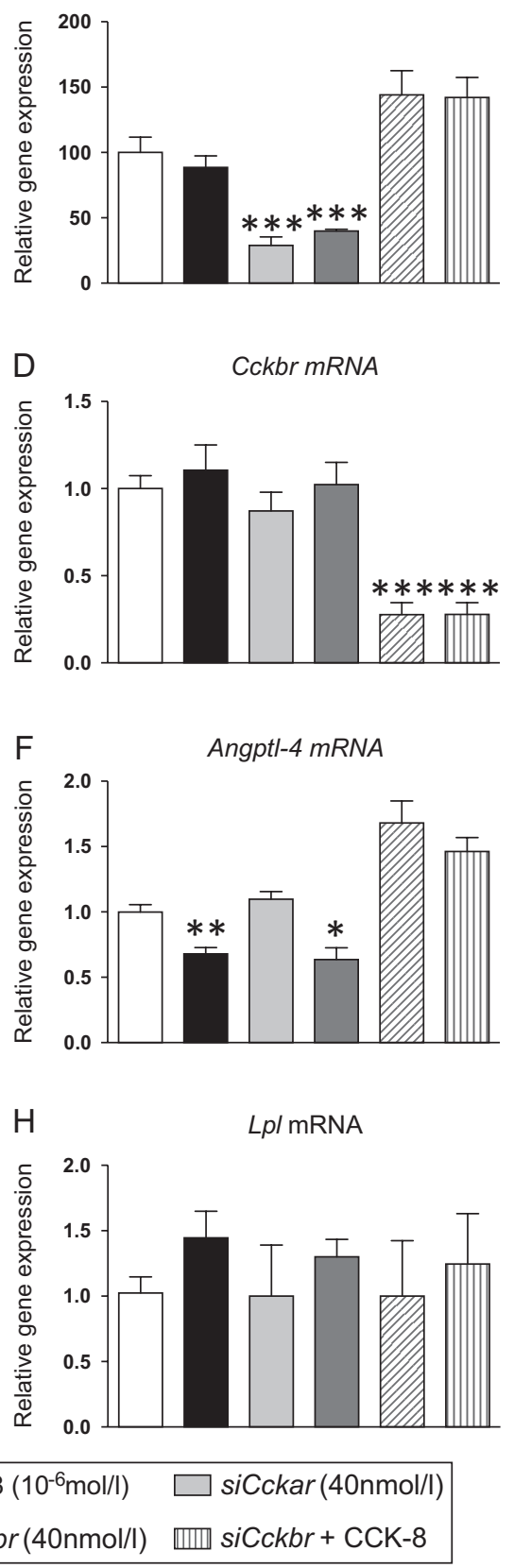

Figure 4

Effect of acute treatment with CCK-8 on Angptl-4 expression in visceral and subcutaneous pre-adipocytes. A and B and C and D panels illustrate the efficacy of the silencing procedure in Cckar and Cckbr expression, respectively. CCK-8 $\left(10^{-6} \mathrm{mmol} / \mathrm{L}\right)$ inhibited Angptl-4 expression in pre-adipocytes obtained from perirenal $(E)$ and subcutaneous WAT (F). CCK-8 had no effect on Lp/ expression in both types of pre-adipocytes ( $G$ and $\mathrm{H})$. Angptl-4 and $L p /$ values were normalized to the housekeeping gene 185 ribosomal RNA and $\beta$-actin. $C c k b r$, but not $C c k a r$, expression silencing fully prevented the effect of CCK-8 in both pre-adipocyte populations. Values are means \pm S.E.M. $(n=5) .{ }^{*} P<0.05, * * P<0.01$, $* * * P<0.001$ compared to the control group (Newman Keuls' test). us to discard the influence of the decrease of food intake triggered by CCK-8 on Angptl-4 gene expression/ LPL activity. In regards to the CCK receptor subtype involved in CCK-8 effects, our data demonstrate the specific involvement of CCK-2R. Importantly, the effect of CCK-8 was not diminished after chronic exposition to this hormone, suggesting that CCK-2R-mediated effects are apparently not submitted to desensitization mechanisms. This result would be coherent with a lack of tolerance to CCK-2R-mediated effects and might have

$\begin{array}{lr}\begin{array}{l}\text { http://joe.endocrinology-journals.org } \\ \text { https://doi.org/10.1530/JOE-17-0580 }\end{array} & \text { ○ } 2018 \text { Society for Endocrinology } \\ \text { Published by Bioscientifica Ltd. } \\ \text { Printed in Great Britain }\end{array}$

important implications for eventual therapeutic uses of CCK analogues.

The downregulation of adipose Angptl-4 gene expression is coherent with the decrease of plasma ANGPTL-4 concentration, as WAT is one of the main sources of circulating ANGPTL-4 (Yoon et al. 2000, Bergö et al. 2002) and suggest an autocrine/paracrine effect of ANGPTL-4 on LPL activity in this tissue. This possibility is supported by the lack of effect of CCK- 8 on both Angptl-4 and Lpl mRNA levels within the liver (Fig. 3 and 


\begin{tabular}{|c|c|c|c|}
\hline $\begin{array}{l}\text { Journal of } \\
\text { Endocrinologv }\end{array}$ & A Plaza, B Merino et al. & $\begin{array}{l}\text { Cholecystokinin and adipose } \\
\text { tissue metabolism }\end{array}$ & 146 \\
\hline
\end{tabular}
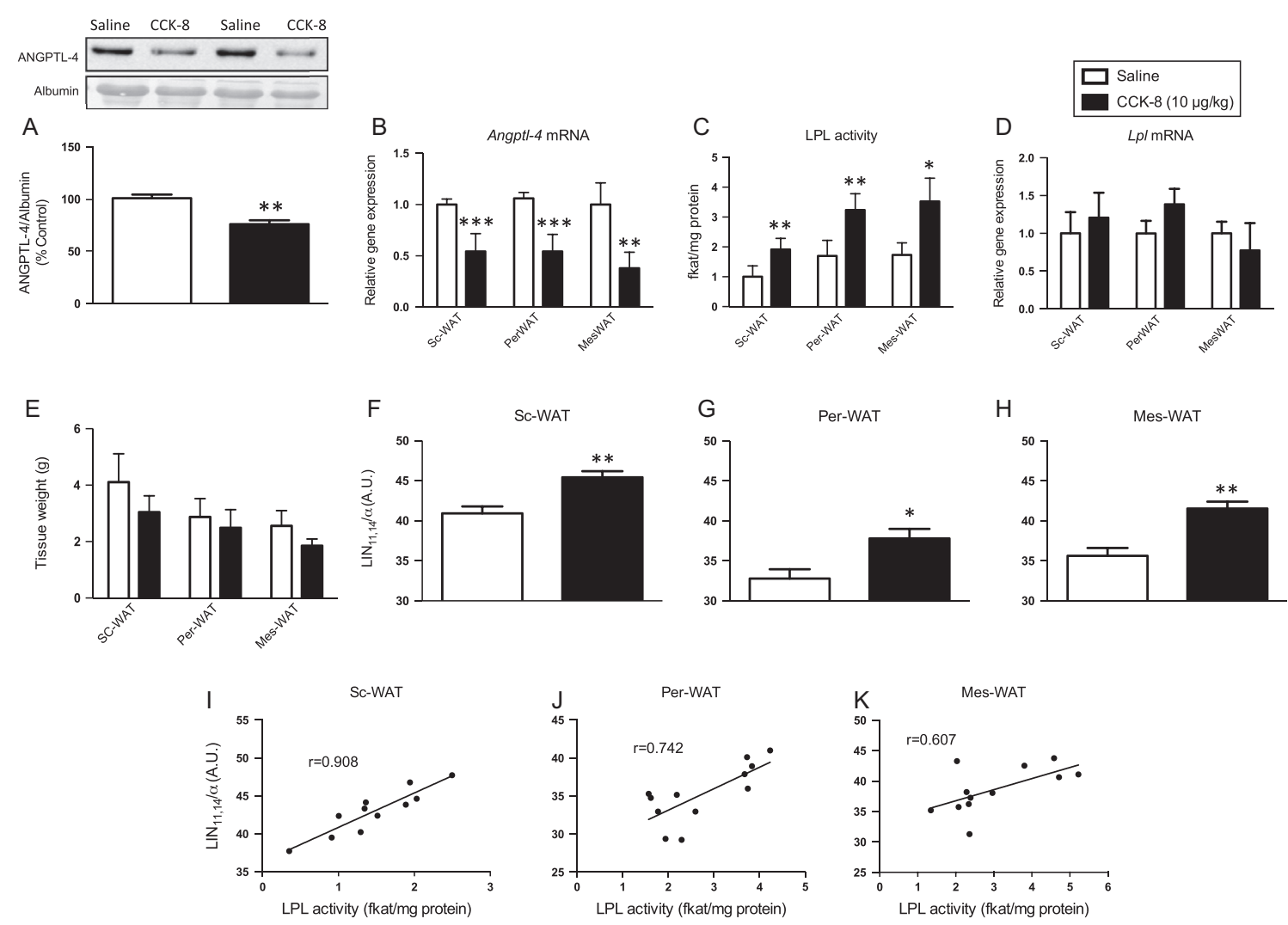

Figure 5

Effect of chronic CCK-8 on Angptl-4 expression, LPL activity, adiposity, triglyceride uptake in subcutaneous and visceral adipose tissues and plasma biochemistry. Chronic CCK-8 decreased circulating ANGPTL-4 (A), repressed Angptl-4 expression in subcutaneous and visceral WAT (B), and enhanced LPL activity (C). Lp/ expression was not modified by chronic CCK-8 (D). Angptl-4 values were normalized to the housekeeping gene $\beta$-actin and 185 ribosomal RNA. The total amount of adipose tissues was not modified by chronic CCK-8 (E), but the uptake of linolenic/linoleic acid was enhanced in all WAT deposits $(F, G$ and $H)$. Correlations between $\operatorname{LIN}_{11,14} / \alpha$ and $L P L$ activity $(I, J$ and $K)$. Values are means \pm s.E.M. $(n=6) .{ }^{*} P<0.05, * * P<0.01$ and $* * * P<0.001$ compared to the control group (Newman-Keuls' test).

supplementary data), which is the other relevant origin of ANGPTL-4 in rodents. The finding that CCK-8 downregulates Angptl-4 gene expression in pre-adipocytes, together with the specific blockage of this response in cells when the CCK-2R gene is silenced, further demonstrates the involvement of adipocyte CCK-2R on CCK-8 effects and gives support to the concept that CCK systems within WAT play a role on the regulation of LPL in WAT. Nevertheless, although our data strongly suggest that an increase in LPL activity reflects the activation of endothelial LPL, the activation of non-endothelial pools of LPL cannot be excluded.

Our current data show that the adipotrophic effect of CCK-8 might be endowed with physiological relevance for lipid and energy homeostasis and be complementary to insulin's actions in regulating TG storage (Czech et al. 2013). It should be noted that a possible CCK-8-mediated increase in intestinal absorption of TG could theoretically account for CCK-8's effects. However, this possibility can be ruled out as the highest dose used in the study $(10 \mu \mathrm{g} / \mathrm{kg})$ did not increase the absorption rate constant $\left(\mathrm{k}_{\mathrm{a}}\right)$ or the bioavailability of orally administered TGs (Fig. 1 and supplementary data). In addition to this, the lack of effect of acute CCK-8 on plasma TG, together with the decrease detected after chronic treatment, support the concept that CCK-8's effects on WAT are not linked to a rise in plasma TG. In any case, the effect of CCK-8 does not appear to be associated to an increase in plasma insulin levels, as CCK-8 failed to modify plasma insulin levels and even triggered a significant decrease of the hormone in chronically treated animals. These data are in apparent contradiction with the role of CCK as an insulin secretagogue (Ahrén \& Lundquist 1981, Verspohl et al. 1986, Rossetti et al. 1987, Lo et al. 2011), and particularly with the study by Ahrén et al. (2000), reporting an increase in plasma insulin after CCK infusion (Ahrén et al. 2000). Our results could be due to the different experimental conditions. Thus, Ahrén and coworkers administered 


\begin{tabular}{l|l|l||c|}
$\begin{array}{l}\text { Journal of } \\
\text { Endocrinology }\end{array}$ & A Plaza, B Merino et al. & $\begin{array}{l}\text { Cholecystokinin and adipose } \\
\text { tissue metabolism }\end{array}$ & $\mathbf{2 3 6 : 3}$ \\
\hline
\end{tabular}

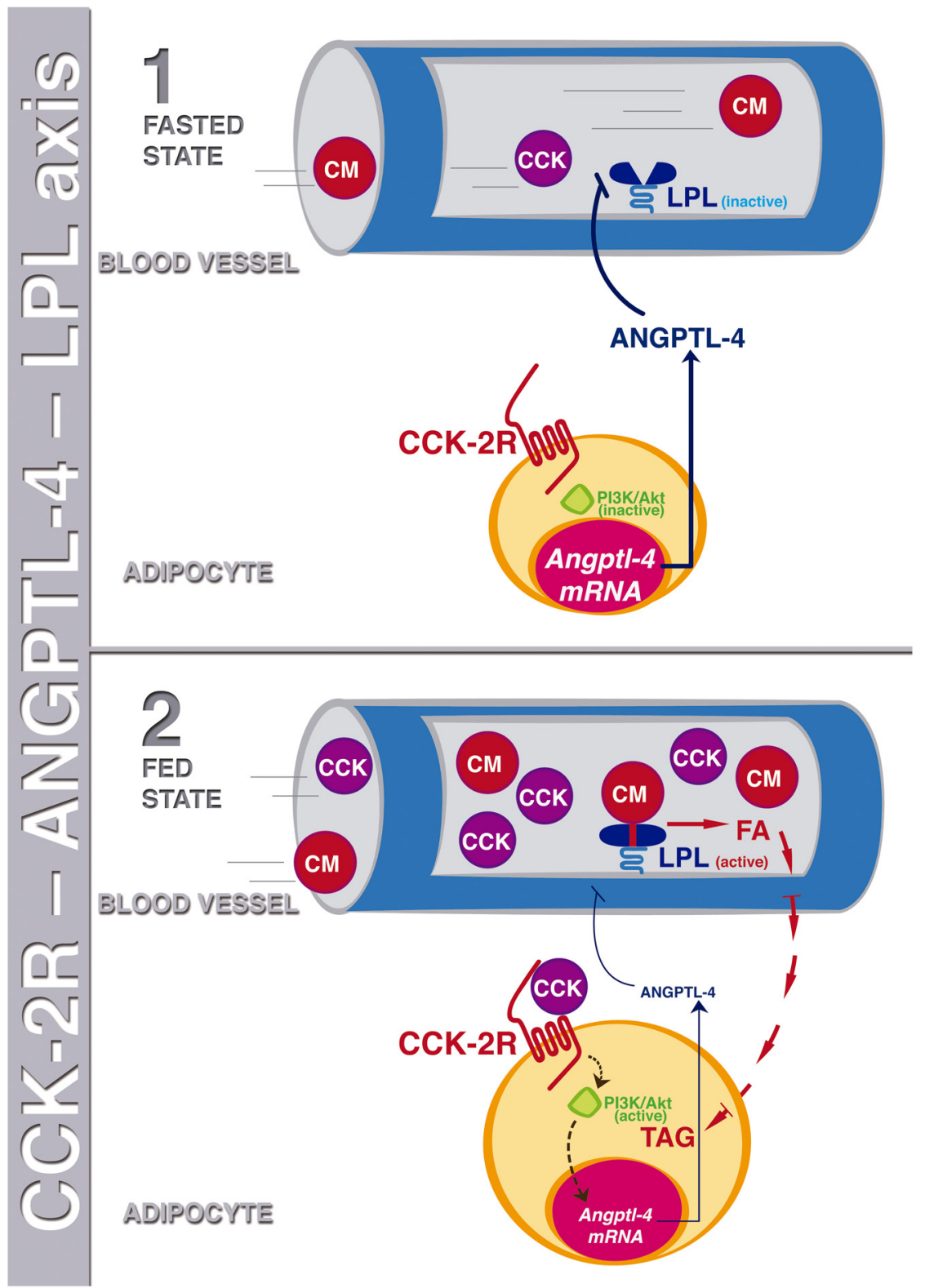

\begin{abstract}
Figure 6
Proposed model of regulation of the lipoprotein lipase (LPL)-angiopoietin-like protein-4 (ANGPTL-4) axis by CCK-8. (1) During fasting, CCK-2 binding sites are poorly occupied as plasma levels of CCK remain low. Under these conditions signaling pathways downstream CCK-2R (for instance, PI3K/Akt signaling pathway) display low activity and the Angptl-4 gene is transcribed. Therefore plasma levels of ANGPTL-4 are elevated, and LPL remains inactive (low activity). (2) In postprandial periods, increased levels of CCK and further occupation of CCK-2R promote the activation of PI3K/Akt, and repress the expression of Angptl-4, by acting on CCK-2R in adipocytes. As a consequence, plasma ANGPTL-4 levels decrease and LPL become active, allowing the uptake of fatty acids by WAT. CM, chylomicrons; TAG, triglycerides.
\end{abstract}

CCK-8 at a constant flow during 90 min to humans that adhered to a similar food intake protocol. In our study, an i.p. bolus of CCK was administered to free-feeding rats. In accordance with the satiating effect of CCK, animals receiving CCK-8 displayed a significant decrease in food intake, that taken together with the inhibitory effect of CCK-8 on gastric emptying (Fried et al. 1991), could balance the insulin secretagogue effect of CCK-8. In regard to the different basal insulin levels observed in rats submitted to the acute/chronic treatment, it can be argued that differences in the experimental protocol may explain why chronically treated rats (that received an i.p. injection of saline $6 \mathrm{~h}$ before sacrifice) displayed higher insulin values than acutely treated rats (submitted

\begin{tabular}{|lr}
\hline http://joe.endocrinology-journals.org & ○ 2018 Society for Endocrinology \\
https://doi.org/10.1530/JOE-17-0580 & Published by Bioscientifica Ltd. \\
Printed in Great Britain
\end{tabular}

to the same protocol, but $2 \mathrm{~h}$ before sacrifice). In fact, stress has been shown to inhibit insulin release (Begg \& Woods 2013, Kuo et al. 2015). Therefore, targeting CCK pathways might be a useful strategy to improve hypertriglyceridemia (HTG) in diabetes. This is relevant because HTG is a main metabolic disorder integral to the cluster of diabetes-associated cardiovascular risks that remains partially unresolved (Chait \& Goldberg 2017). In any case, further research focusing on the effect of CCK-8 on HTG management in experimental models of diabetes is necessary to assess such a possibility.

The effect of CCK-8 was not due to an increase of plasma leptin as acute CCK-8 did not significantly modify leptin levels. As observed in the case of insulin, chronic 
CCK-8 treatment also decreased plasma leptin, a finding that could be linked to the inhibitory effect of CCK-8 on BW. An important question that emerges from these data concerns the adequacy of the dose-range of CCK-8 used in our study. Most of the experiments have been carried out with the dose of $10 \mu \mathrm{g} / \mathrm{kg}$, a dose that apparently yields plasma CCK concentrations within the physiological range (Cano et al. 2008). In accordance, plasma CCK levels were not modified by CCK-8 in our study. It should be noted that the relatively rapid degradation of CCK (Koulischer et al. 1982) could mask the influence of exogenous CCK-8 on total CCK levels. In addition, commercial CCK antibodies used for CCK quantification recognize a mixture of molecular forms derived from pre-proCCK that are present in blood (Reeve et al. 1986), making proper quantification of plasma bioactive CCK fragments difficult.

The effect of acute CCK-8 on Angptl-4 gene expression and LPL activity is endowed with functional consequences as CCK-8-treated animals that consumed linolenic/linoleic acid (LIN)-enriched fat incorporated LIN to WAT more efficiently than their saline-treated counterparts. This finding is supported by the positive correlation between LPL activity and the ability of the different adipose tissues analyzed to incorporate LIN. Interestingly, the effect of chronic CCK-8 on Angptl-4 mRNA levels, LPL activity and LIN uptake was similar to that observed after acute treatment with the hormone, suggesting the lack of tolerance to this CCK effect. Finally, the CCK-2R antagonist, L-365,260, specifically blocked the effect of CCK-8 on LIN uptake giving further support to the involvement of CCK-2Rs in dietary TGs management.

Taken together, the results of the current study support the concept of a CCK-2R/ANGPTL-4/LPL axis that regulates postprandial uptake of TG into WAT (Fig. 6) and completes the mechanisms proposed by Dijk \& Kersten (Dijk \& Kersten 2014) concerning the relevance of an ANGPTL-4/LPL axis aimed at clearing TGs from both chylomicrons and VLDL proteins. In regard to the mechanism involved in CCK-8-mediated repression of Angptl-4 expression and decrease of plasma ANGPTL-4 levels, a plausible possibility would involve the PI3K/Akt pathway as this signalling pathway, which has been shown to be pivotal for insulin-mediated repression of the Angptl-4 gene (Kuo et al. 2014), is activated by CCK-2R (Dufresne et al. 2006). In any case, the versatility of downstream signaling pathways coupled to CCK-2R (Dufresne et al. 2006) allows one to hypothesize the involvement of other signaling pathways, such as PPAR- $\gamma$ (Burns \& Heuvel 2007), that is also known to govern Angptl-4 expression.

(C) 2018 Society for Endocrinology Published by Bioscientifica Ltd. Printed in Great Britain
It is important to highlight that ANGPTL-4, in addition to its role in regulating TG uptake, has been shown to govern angiogenesis in adipose tissue (Hato et al. 2008). Although data in the literature are controversial, and some studies have demonstrated an anti-angiogenic effect of the C-terminal domain of ANGPTL-4 (Yang et al. 2008), most studies have identified ANGPTL-4 as a potent pro-angiogenic and anti-inflammatory agent that favors the expandability of WAT (Kadomatsu et al. 2011). In this context, the potential use of CCK-related drugs to improve WAT functionality in insulin-resistant conditions might be limited by an eventual inhibition of angiogenesis. Moreover, the lack of data in regard to the effect of CCK-8 on human WAT limits the impact of our study in order to design pharmacotherapeutic strategies based on the use of CCK analogues as tools for insulin resistance management. In any case, the possibility that the system conformed by CCK receptors, LPL and ANGPTL-4 could be an important target for improving metabolism deserves further attention and should be validated in human WAT.

\section{Supplementary data}

This is linked to the online version of the paper at https://doi.org/10.1530/ JOE-17-0580.

Declaration of interest

The authors declare that there is no conflict of interest that could be perceived as prejudicing the impartiality of this research reported.

\section{Funding}

Ministerio de Economía y Competitividad (BFU2016-78556R, BFU201451836-C2-2-R; BFU 2012-35353; CTQ2015-64624-R), European Regional Development Fund, Universidad San Pablo-CEU and CIBEROBN. F H-N and $D D-R$ are supported by the postgraduate fellowship program of Universidad San Pablo-CEU. A P is a postgraduate fellow of Ministerio de Economía y Competitividad (BES-2012-063773).

\section{Author contribution statement}

A $P, V C, G D, J P-C$ and $B$ M contributed to data acquisition and interpretation. B M, C S, J A C and M R-G designed the study and wrote the manuscript. J P-C, M F-A, C S, J A C and M R-G drafted and revised the manuscript. All authors approved the final version of the manuscript.

\section{Acknowledgements}

The authors would like to thank I Isla-Gayo for Fig. 6 design, and S Álvarez for helpful technical assistance. 


\section{References}

Ahrén B \& Lundquist I 1981 Effects of two cholecystokinin variants, CCK-39 and CCK-8, on basal and stimulated insulin secretion. Acta Diabetologica 18 345-356. (https://doi.org/10.1007/BF02042819)

Ahrén B, Holst JJ \& Efendic S 2000 Antidiabetogenic action of cholecystokinin-8 in type 2 diabetes. Journal of Clinical Endocrinology and Metabolism 85 1043-1048. (https://doi.org/10.1210/jcem.85.3.6431)

Attoub S, Levasseur S, Buyse M, Goïot H, Laigneau J-P, Moizo L, Hervatin F, Le Marchand-Brustel Y, Lewin JM \& Bado A 1999 Physiological role of cholecystokinin B/gastrin receptor in leptin secretion 1. Endocrinology 140 4406-4410. (https://doi.org/10.1210/ endo.140.10.7079)

Begg DP \& Woods SC 2013 Interactions between the central nervous system and pancreatic islet secretions: a historical perspective. Advances in Physiology Education 37 53-60. (https://doi.org/10.1152/ advan.00167.2012)

Bergö M, Wu G, Ruge T \& Olivecrona T 2002 Down-regulation of adipose tissue lipoprotein lipase during fasting requires that a gene, separate from the lipase gene, is switched on. Journal of Biological Chemistry 277 11927-11932. (https://doi.org/10.1074/jbc.M200325200)

Burns KA \& Heuvel JPV 2007 Modulation of PPAR activity via phosphorylation. Biochimica et Biophysica Acta (BBA): Molecular and Cell Biology of Lipids 1771 952-960. (https://doi.org/10.1016/j. bbalip.2007.04.018)

Cano V, Ezquerra L, Pilar Ramos M \& Ruiz-Gayo M 2003 Characterization of the role of endogenous cholecystokinin on the activity of the paraventricular nucleus of the hypothalamus in rats. British Journal of Pharmacology 140 964-970. (https://doi.org/10.1038/sj.bjp.0705513)

Cano V, Merino B, Ezquerra L, Somoza B \& Ruiz-Gayo M 2008 A cholecystokinin-1 receptor agonist (CCK-8) mediates increased permeability of brain barriers to leptin. British Journal of Pharmacology 154 1009-1015. (https://doi.org/10.1038/bjp.2008.149)

Cantor P \& Rehfeld JF 1989 Cholecystokinin in pig plasma: release of components devoid of a bioactive $\mathrm{COOH}$-terminus. American Journal of Physiology: Gastrointestinal and Liver Physiology 256 G53-G61. (https://doi.org/10.1152/ajpgi.1989.256.1.G53)

Chait A \& Goldberg I 2017 Treatment of dyslipidemia in diabetes: recent advances and remaining questions. Current Diabetes Reports 17112 (https://doi.org/10.1007/s11892-017-0942-8)

Chang R, Chen T, Bock M, Freidinger R, Chen R, Rosegay A \& Lotti V 1989 Characterization of the binding of [3H] L-365,260: a new potent and selective brain cholecystokinin (CCK-B) and gastrin receptor antagonist radioligand. Molecular Pharmacology 35 803-808.

Czech MP, Tencerova M, Pedersen DJ \& Aouadi M 2013 Insulin signalling mechanisms for triacylglycerol storage. Diabetologia 56 949-964. (https://doi.org/10.1007/s00125-013-2869-1)

Demenis C, McLaughlin J \& Smith CP 2017 Sulfated cholecystokinin-8 promotes CD36-mediated fatty acid uptake into primary mouse duodenal enterocytes. Frontiers in Physiology 8 660. (https://doi. org/10.3389/fphys.2017.00660)

Dijk W \& Kersten S 2014 Regulation of lipoprotein lipase by Angptl4. Trends in Endocrinology and Metabolism 25 146-155. (https://doi. org/10.1016/j.tem.2013.12.005)

Dufresne M, Seva C \& Fourmy D 2006 Cholecystokinin and gastrin receptors. Physiological Reviews 86 805-847. (https://doi.org/10.1152/ physrev.00014.2005)

Fried M, Erlacher U, Schwizer W, Löchner C, Koerfer J, Beglinger C, Jansen JB, Lamers CB, Harder F \& Bischof-Delaloye A 1991 Role of cholecystokinin in the regulation of gastric emptying and pancreatic enzyme secretion in humans: studies with the cholecystokininreceptor antagonist loxiglumide. Gastroenterology 101 503-511. (https://doi.org/10.1016/0016-5085(91)90031-F)

Hato T, Tabata M \& Oike Y 2008 The role of angiopoietin-like proteins in angiogenesis and metabolism. Trends in Cardiovascular Medicine $\mathbf{1 8}$ 6-14. (https://doi.org/10.1016/j.tcm.2007.10.003)
Herrera E \& Ayanz A 1972 Calculation of lipolysis and esterification from glycerol metabolism in rat adipose tissue. Journal of Lipid Research $\mathbf{1 3}$ 802-809.

Irwin N, Montgomery I \& Flatt P 2013a Comparison of the metabolic effects of sustained CCK1 receptor activation alone and in combination with upregulated leptin signalling in high-fat-fed mice. Diabetologia 56 1425-1435. (https://doi.org/10.1007/s00125-0132878-0)

Irwin N, Frizelle P, O'Harte FP \& Flatt PR $2013 b$ (pGlu-Gln)-CCK-8 [mPEG]: a novel, long-acting, mini-PEGylated cholecystokinin (CCK) agonist that improves metabolic status in dietary-induced diabetes. Biochimica et Biophysica Acta (BBA): General Subjects 1830 4009-4016. (https://doi.org/10.1016/j.bbagen.2013.04.004)

Kadomatsu T, Tabata M \& Oike Y 2011 Angiopoietin-like proteins: emerging targets for treatment of obesity and related metabolic diseases. FEBS Journal 278 559-564. (https://doi.org/10.1111/j.17424658.2010.07979.x)

King A, Yang Q, Huesman S, Rider T \& Lo CC 2015 Lipid transport in cholecystokinin knockout mice. Physiology and Behavior 151 198-206. (https://doi.org/10.1016/j.physbeh.2015.07.009)

Knothe G \& Kenar JA 2004 Determination of the fatty acid profile by 1H-NMR spectroscopy. European Journal of Lipid Science and Technology 106 88-96. (https://doi.org/10.1002/ejlt.200300880)

Koulischer D, Moroder L \& Deschodt-Lanckman M 1982 Degradation of cholecystokinin octapeptide, related fragments and analogs by human and rat plasma in vitro. Regulatory Peptides 4 127-139. (https://doi.org/10.1016/0167-0115(82)90080-5)

Kuo T, Chen T-C, Yan S, Foo F, Ching C, McQueen A \& Wang J-C 2014 Repression of glucocorticoid-stimulated angiopoietin-like 4 gene transcription by insulin. Journal of Lipid Research 55 919-928. (https:// doi.org/10.1194/jlr.M047860)

Kuo T, McQueen A, Chen T-C \& Wang J-C 2015 Regulation of glucose homeostasis by glucocorticoids. In Glucocorticoid Signaling: From Molecules to Mice to Man, pp 99-126. Eds J-C Wang \& C Harris. Berlin, Germany: Springer. (https://doi.org/10.1007/978-1-4939-2895-8_5)

Lee MJ, Pickering RT \& Puri V 2014 Prolonged efficiency of siRNA-mediated gene silencing in primary cultures of human preadipocytes and adipocytes. Obesity 22 1064-1069. (https://doi. org/10.1002/oby.20641)

Livak KJ \& Schmittgen TD 2001 Analysis of relative gene expression data using real-time quantitative PCR and the $2-\Delta \Delta \mathrm{CT}$ method. Methods $\mathbf{2 5}$ 402-408. (https://doi.org/10.1006/meth.2001.1262)

Lo CM, King A, Samuelson LC, Kindel TL, Rider T, Jandacek RJ, Raybould HE, Woods SC \& Tso P 2010 Cholecystokinin knockout mice are resistant to high-fat diet-induced obesity. Gastroenterology 138 1997-2005. (https://doi.org/10.1053/j.gastro.2010.01.044)

Lo C-M, Obici S, Dong HH, Haas M, Lou D, Kim DH, Liu M, D'Alessio D, Woods SC \& Tso P 2011 Impaired insulin secretion and enhanced insulin sensitivity in cholecystokinin-deficient mice. Diabetes 60 2000-2007. (https://doi.org/10.2337/db10-0789)

Merino B, Cano V, Guzman R, Somoza B \& Ruiz-Gayo M 2008a Leptinmediated hypothalamic pathway of cholecystokinin (CCK-8) to regulate body weight in free-feeding rats. Endocrinology 149 1994-2000. (https://doi.org/10.1210/en.2007-1286)

Merino B, Somoza B, Ruiz-Gayo M \& Cano V 2008b Circadian rhythm drives the responsiveness of leptin-mediated hypothalamic pathway of cholecystokinin-8. Neuroscience Letters 442 165-168. (https://doi. org/10.1016/j.neulet.2008.07.009)

Montgomery I, Irwin N \& Flatt P 2013 Beneficial effects of (pGluGln)-CCK-8 on energy intake and metabolism in high fat fed mice are associated with alterations of hypothalamic gene expression. Hormone and Metabolic Research 45 471-473. (https://doi. org/10.1055/s-0032-1331767)

Moran TH \& Bi S 2006 Hyperphagia and obesity of OLETF rats lacking CCK1 receptors: developmental aspects. Developmental Psychobiology 48 360-367. (https://doi.org/10.1002/dev.20149) 
Morton GJ, Blevins JE, Williams DL, Niswender KD, Gelling RW, Rhodes CJ, Baskin DG \& Schwartz MW 2005 Leptin action in the forebrain regulates the hindbrain response to satiety signals. Journal of Clinical Investigation 115 703. (https://doi.org/10.1172/ JCI200522081)

Mosconi E, Fontanella M, Sima DM, Van Huffel S, Fiorini S, Sbarbati A \& Marzola P 2011 Investigation of adipose tissues in Zucker rats using in vivo and ex vivo magnetic resonance spectroscopy. Journal of Lipid Research 52 330-336. (https://doi.org/10.1194/jlr.M011825)

Owyang C \& Logsdon CD 2004 New insights into neurohormonal regulation of pancreatic secretion. Gastroenterology 127 957-969. (https://doi.org/10.1053/j.gastro.2004.05.002)

Pauli GF, Gödecke T, Jaki BU \& Lankin DC 2012 Quantitative 1H NMR. Development and potential of an analytical method: an update. Journal of Natural Products 75 834-851. (https://doi.org/10.1021/ np200993k)

Poncelet M, Arnone M, Heaulme M, Gonalons N, Gueudet C, Santucci V, Thurneyssen O, Keane P, Gully D \& Le Fur G 1993 Neurobehavioural effects of SR 27897, a selective cholecystokinin type A (CCK-A) receptor antagonist. Naunyn-Schmiedeberg's Archives of Pharmacology 348 102-107. (https://doi.org/10.1007/BF00168544)

Reeve J, Eysselein V, Walsh JH, Ben-Avram CM \& Shively JE 1986 New molecular forms of cholecystokinin. Microsequence analysis of forms previously characterized by chromatographic methods. Journal of Biological Chemistry 261 16392-16397.

Rossetti L, Shulman GI \& Zawalich WS 1987 Physiological role of cholecystokinin in meal-induced insulin secretion in conscious rats: studies with L 364718, a specific inhibitor of CCK-receptor binding. Diabetes 36 1212-1215. (https://doi.org/10.2337/diab.36.10.1212)

Ruiz-Gayo M, Garrido MM \& Fuentes JA 2000 Inhibition of the hypothalamic-pituitary-adrenal axis in food-deprived rats by a CCK-A receptor antagonist. British Journal of Pharmacology 129 839-842. (https://doi.org/10.1038/sj.bjp.0703117)
Schroeder M, Zagoory-Sharon O, Shbiro L, Marco A, Hyun J, Moran TH, Bi S \& Weller A 2009 Development of obesity in the Otsuka LongEvans Tokushima fatty rat. American Journal of Physiology: Regulatory, Integrative and Comparative Physiology 297 R1749-R1760. (https://doi. org/10.1152/ajpregu.00461.2009)

Sugden MC, Holness MJ \& Howard RM 1993 Changes in lipoprotein lipase activities in adipose tissue, heart and skeletal muscle during continuous or interrupted feeding. Biochemical Journal 292 113-119. (https://doi.org/10.1042/bj2920113)

Sukonina V, Lookene A, Olivecrona T \& Olivecrona G 2006 Angiopoietinlike protein 4 converts lipoprotein lipase to inactive monomers and modulates lipase activity in adipose tissue. PNAS 103 17450-17455. (https://doi.org/10.1073/pnas.0604026103)

Verspohl EJ, Ammon HP, Williams JA \& Goldfine ID 1986 Evidence that cholecystokinin interacts with specific receptors and regulates insulin release in isolated rat islets of Langerhans. Diabetes 35 38-43. (https:// doi.org/10.2337/diab.35.1.38)

Weng J, Lou D, Benoit SC, Coschigano N, Woods SC, Tso P \& Lo CC 2017 Energy homeostasis in apolipoprotein AIV and cholecystokinindeficient mice. American Journal of Physiology: Regulatory, Integrative and Comparative Physiology 313 R535-R548. (https://doi.org/10.1152/ ajpregu.00034.2017)

Yang Y-H, Wang Y, Lam KS, Yau M-H, Cheng KK, Zhang J, Zhu W, Wu D $\&$ Xu A 2008 Suppression of the Raf/MEK/ERK signaling cascade and inhibition of angiogenesis by the carboxyl terminus of angiopoietinlike protein 4. Arteriosclerosis, Thrombosis, and Vascular Biology $\mathbf{2 8}$ 835-840. (https://doi.org/10.1161/ATVBAHA.107.157776)

Yoon JC, Chickering TW, Rosen ED, Dussault B, Qin Y, Soukas A, Friedman JM, Holmes WE \& Spiegelman BM 2000 Peroxisome proliferator-activated receptor $\gamma$ target gene encoding a novel angiopoietin-related protein associated with adipose differentiation. Molecular and Cellular Biology 20 5343-5349. (https://doi.org/10.1128/ MCB.20.14.5343-5349.2000)

Received in final form 16 December 2017

Accepted 16 January 2018

Accepted Preprint published online 16 January 2018 